\title{
Cyfrowe narzędzia w dydaktyce akademickiej Badania diachroniczne polskiej fleksji z użyciem systemu Chronofleks
}

\author{
Digital Tools in Academic Didactics \\ Diachronic Description of Polish Inflection \\ Using the Chronofleks System
}

\begin{abstract}
This paper describes the possibilities of the diachronic description of Polish inflection by the Chronofleks system and using it in academic didactics of historical linguistics classes. In new didactic seems necessary to use solutions based on new technologies that use students' digital skills. Therefore, the observations carried out were to check the extent to which Chronofleks is helpful both in verifying the information available in academic tertbooks and in the independent acquisition of knowledge by students. Three grammar issues were selected for research: Kopczyński's rules, distribution of historic singular endings of male nouns, and ending frequency of the first person plural of verbs. The tests showed that a student can successfully learn the morphology of old Polish using the Chronofleks tool. In addition, Chronofleks allows you to implement a self-study teaching model.
\end{abstract}

Key words: academic didactics, digital tools in academic didactics, Chronofleks system, diachronic description of Polish inflection

\begin{abstract}
Abstrakt: W artykule sprawdzane są możliwości wykorzystania systemu Chronofleks w dydaktyce akademickiej przedmiotów historycznojęzykowych. Autorka wybrała trzy zagadnienia fleksyjne: funkcjonowanie $w$ uzusie tzw. reguły Kopczyńskiego, dystrybucję historycznych końcówek D. I. poj. r.m. rzeczowników oraz frekwencję zakończeń - $m$, -my końcówki 1. os. I. mn. czasowników. Przeprowadzone testy wykazały, że automatyczne wyszukiwanie w systemie działa sprawnie, a wyniki prac wizualizowane są $w$ przejrzystej formie. Dzięki wykorzystaniu posiadanych sprawności cyfrowych student może zdobywać nową wiedzę. Może on zatem samodzielnie uczyć się morfologii dawnej polszczyzny z użyciem systemu, jednak powinien wspierać go nauczyciel, czuwając nad wyciąganiem prawidłowych wniosków. Realizowany w ten sposób model dydaktyczny nastawiony na samokształcenie może uatrakcyjnić ofertę dydaktyczną uczelni wyższych.
\end{abstract}

Słowa kluczowe: dydaktyka akademicka, narzędzia cyfrowe w dydaktyce akademickiej, system Chronofleks, diachroniczny opis fleksji polskiej

\section{Wstęp}

Konieczność wykorzystywania $w$ dydaktyce akademickiej nowych technologii przyjmowana jest dziś bez większych zastrzeżeń. Interaktywność i multimedialność mogą podnosić 
atrakcyjność prezentowanych treści, jednak nie ma pewności, że hipertekstowa i polisensoryczna forma przekazu zwiększają jego skuteczność (por. CUBAN, 2001; SPITzER, 2007; KUREK, 2013; MAYER, 2013). Użycie technologii i narzędzi cyfrowych w procesie nauczania wydaje się niezbędne z innego, bardziej fundamentalnego powodu. Obecni studenci to osoby urodzone w latach 90. ubiegłego wieku, które wzrastały otoczone nowymi technologiami. "Cyfrowi tubylcy"1 nie znają rzeczywistości bez Internetu. Sieć komputerowa, laptop, telefon (smartfon) to dla nich naturalne elementy otaczającego świata, które służą zarówno komunikacji międzyludzkiej, jak i pozyskiwaniu informacji. Stanowią źródło wiedzy, narzędzie do nauki i pracy, a przy tym dostarczają rozrywki. Dla pokolenia $Y^{2}$ urządzenia cyfrowe są nieodłączną częścią życia. Za sprawą możliwości technicznych jednocześnie prowadzi się rozmowę i przegląda strony internetowe; ogląda film, słucha muzyki, wysyła wiadomości. W ten sposób łączy się w jednym urządzeniu funkcje między innymi telefonu, telewizora i odtwarzacza muzyki. Konwergencja multimediów, czyli ich wzajemne przenikanie się, spowodowane ciągłym rozwojem technologii, zmusza młode osoby do bycia wielozadaniowymi (КорескA-PIECH, 2011: 11-25). Aplikacje i oprogramowanie szybko się zmieniają, co pociąga za sobą niezwykłą różnorodność dostępnych środków wyrazu i konieczność opanowania ich funkcji. Prognozuje się, że w przyszłości hipermedia nie będą limitowane ekranem komputera. Konstruowane są właśnie aplikacje osadzone w naszym codziennym środowisku: w ubraniach, meblach, samochodach.

Aktualny profil studenta uświadamia, że:

[j]edynym sensownym i praktycznie uzasadnionym powodem wprowadzania technologii $w$ obszar nauczania nie jest więc ich hipotetyczna rola narzędzia zwiększającego efektywność dydaktyczną, lecz rzeczywista i pragmatyczna rola narzędzia codziennej pracy, nauki i zabawy poza szkołą.

WoBALIS, 2017: 448

Cyfrowe umiejętności studentów warto wykorzystać w dydaktyce. Działania akademickie będą dzięki temu w stylu i sposobie bliższe codzienności „cyfrowych tubylców” i bardziej z nią spójne. Jednak posiadany przez studentów warsztat technologiczny należałoby również $w$ odpowiedni sposób ukierunkować, by pomóc uczącym się odnaleźć wiarygodne i stabilne oparcie pośród dynamicznie zmieniającego się świata mediów elektronicznych.

Należy zwrócić uwagę na to, że technologie informacyjne, choć podnoszą komfort nauki i zwiększają elastyczność pracy, powodują też rozproszenie uwagi i spadek efektywności zapamiętywania (SPItzer, 2013; 2016). Postęp cywilizacyjny i związana z nim szybkość oraz wygoda dotarcia do wiedzy sprawiają, że - żartobliwie nazywanym - wieloletnim uczniom „wujka Googla i cioci Wiki” (Szewко, 2012) brakuje cierpliwości. Cechuje ich potrzeba ciągłej stymulacji (bo szybko się nudzą) i praktyczne podejście do nauki. Są pewni

1 Twórcą terminu cyfrowi tubylcy (ang. digital natives) jest amerykański badacz mediów Marc PRENSKY (2001ab).

2 Nazwa pokolenia ludzi urodzonych w latach 1980-2000. W literaturze przedmiotu pokolenie Y (ang. Generation Y, Gen Y) określane jest również jako „pokolenia Milenium”, milenialsi (ang. Millennials). Za twórców teorii pokoleń powszechnie uznawani są William Strauss i Neil Howe (1991; $2000)$. 
siebie i oczekują natychmiastowego wynagrodzenia za swoje działania (FAzlagić, 2008). W rzeczywistości młode pokolenie ma problem z selekcją informacji, a czynności wykonuje raczej sekwencjami niż równocześnie (SAJDuK, 2014). Ponadto słabo radzi sobie z krytycznym myśleniem. Szybki dostęp do informacji nie ułatwia bowiem ich interpretacji. Studentom niełatwo jest zająć stanowisko $w$ dyskusji, wyrazić swoją opinię czy samodzielnie przeprowadzić analizę danych. Trudność sprawia im także komunikowanie swoich uczuć i utrzymywanie prawidłowych relacji społecznych (MorbITZER, 2012: 131-153). Dostrzegając ograniczenia uczniów, Dominik Batorski postuluje redefinicję roli komputerów i Internetu $w$ procesie edukacji. Badacz jest zdania, że:

[n]acisk nie powinien być kładziony na naukę kompetencji informatycznych, które dzieci i tak opanowują dość wcześnie same, ale przede wszystkim na naukę kompetencji informacyjnych - tj. pracy z informacją, wyszukiwania, oceny wiarygodności, weryfikacji źródeł, przetwarzania i krytycznej analizy informacji itp., a także rozwój motywacji skłaniających do lepszego korzystania z zasobów znajdujących się $w$ sieci, w tym również ich współtworzenia.

BATORSKI, 2013: 334

Pobieżna analiza zawartości kanałów w serwisie YouTube pozwala zaobserwować, że porad $w$ Internecie udzielają bardzo młode osoby. Zaskakuje również tematyka dostępnych wskazówek: od błahych po bardzo specjalistyczne. Błażej Sajduk interpretuje to zjawisko w kategoriach nobilitacji społecznej:

Możliwość tworzenia wiedzy może wytwarzać w nich [studentach - K.W.] doświadczenie do niedawna dostępne wyłącznie nielicznym. Teraz każdy może poczuć, że jest autorytetem i wzmacniać poczucie własnej wartości. Ma to zapewne przełożenie na proces dydaktyczny, w którym coraz częściej wśród studentów można zaobserwować tendencję, by traktować wywód wykładowcy (i samego wykładowcę) nie jako apriorycznie akceptowaną mądrość, ale opinię prawdopodobną, jak każdą inną.

SAJDUK, 2014: 24

Przegląd literatury na temat przemian sposobów uczenia się i nauczania $w$ dobie mediów cyfrowych pozwala wyróżnić przynajmniej dwa ważne elementy w procesie dydaktycznym. Są to: sposób pozyskiwania wiedzy przez studenta oraz możliwość jej współtworzenia wraz z nauczycielem.

W dalszej części artykułu chciałabym zaprezentować nowe w swej formie i funkcji cyfrowe narzędzie badawcze, które pozwala na włączenie do dydaktyki akademickiej historycznych przedmiotów językoznawczych źródła o wysokiej wiarygodności danych. Student za pomocą programu, który wyszukuje poświadczone $w$ tekstach formy gramatyczne, może uczyć się morfologii dawnej polszczyzny. Program ten pozwala zarówno sprawdzać wiadomości dostępne w podręcznikach, jak i samodzielnie odkrywać wiedzę. Nad prawidłową interpretacją danych językowych musi jednak czuwać wykładowca akademicki. Pod jego merytoryczną opieką student może współtworzyć wiedzę przez przygotowanie nagrań instrukcji ekranowych, tutoriali i screencastów, w których dzieli się wiadomościami z innymi. 
Realizację przykładowych działań dydaktycznych przedstawię, opierając się na systemie Chronofleks i jego technicznych możliwościach.

\section{System Chronofleks - opis ${ }^{3}$}

System Chronofleks powstał w latach 2015-2019 w ramach grantu badawczego finansowanego przez Narodowe Centrum Nauki. Celem projektu OPUS nr 2014/15/B/HS2/03119 było opracowanie formalnego modelu diachronicznego opisu fleksji polskiej i jego komputerowej implementacji. Zadaniem wykonawców projektu było stworzenie narzędzi, które umożliwią zestawianie na przestrzeni lat paradygmatów fleksyjnych pojedynczych leksemów, ich grup, a także kategorii gramatycznych. Wykonawcy projektu to zarówno informatycy, jak i językoznawcy, którzy dzięki ścisłej współpracy przygotowali opis podsystemu fleksyjnego $w$ formie programu komputerowego. Na stronie Instytutu Podstaw Informatyki Polskiej Akademii Nauk (IPI PAN) można przeczytać, że:

[c]elem projektu jest przedstawienie formalnego modelu polskiej fleksji, który umożliwi przedstawienie zmian $w$ polskiej fleksji na przestrzeni dziejów Polski. Model powinien uwzględniać zmiany systemu fleksyjnego jako całości, jak również zmiany poszczególnych leksemów. [...] Ponadto model będzie na tyle ogólny, aby stanowić platformę do prezentacji polskiego systemu fleksyjnego w prospektywnym słowniku diachronicznym.

Chronofleks, online; data dostępu: 7.06.2019

W ramach prac badawczych zespół pod kierownictwem Marcina Wolińskiego stworzył narzędzia informatyczne, które pozwalają na prawidłowe działanie systemu Chronofleks. Wymienić można wśród nich tzw. transkryber, czyli program przekształcający dawny tekst z formy transliterowanej na znormalizowaną ortograficznie wersję transkrybowaną, a także systemy wspomagające przypisywanie formom wyrazowym $w$ tekstach wartości kategorii fleksyjnych (tager, Anotatornia 2) oraz specjalny analizator morfologiczny oparty na słownikach dawnej polszczyzny (Korbeusz). Proces przypisywania wartości gramatycznej wyrazom polega na zastosowaniu automatycznego analizatora form gramatycznych na odpowiednio przygotowanym technicznie materiale językowym. W celu wyeliminowania błędów aplikacji wyniki weryfikowała grupa anotatorów.

Opracowany na potrzeby badań polszczyzny historycznej analizator Korbeusz stanowi wariant systemu Morfeusz (http://morfeusz.sgjp.pl), który przeznaczony jest dla współczesnej polszczyzny (Wolı́́skı, 2014). Podstawą działania Korbeusza są sporządzone przez zespół słowniki fleksyjne, osobno dla polszczyzny XVII i XVIII wieku (słownik oparty na materiale językowym Elektronicznego Korpusu Tekstów Polskich z XVII i XVIII wieku (do 1772 r.), w skrócie Korpusu Barokowego, dalej: KorBa) oraz wieku XIX (słownik na bazie danych Korpusu polszczyzny 1830-1918, dalej: F19). Podczas konstruowania Korbeusza wyko-

${ }^{3}$ Szczegółowych danych i objaśnień na temat systemu Chronofleks udzielili mi Marcin Woliński, kierownik projektu, oraz Dorota Komosińska, programistka w zespole opracowującym opisywany system. 
rzystano dane ze Słownika gramatycznego języka polskiego pod redakcją Zygmunta Saloniego (http://sgjp.pl/leksemy), konieczne było jednak uzupełnienie występujących w nim paradygmatów o wzory regularnie tworzonych dawnych form, które nie występują w tekstach współczesnych. Z uwagi na specyfikę dawnej polszczyzny zmodyfikować należało reguły zarówno fleksyjne, jak i segmentacyjne. Wprowadzono na przykład końcówki liczby podwójnej, formy przymiotników i imiesłowów odmiany niezłożonej, alternatywne końcówki fleksyjne rzeczowników, wzory odmiany nazw własnych, możliwość zapisu partykuły nie łącznie z formami czasownikowymi, reguły przyłączania aglutynantów do szerszej klasy form niż współcześnie, pisownię przyimków łącznie z następującą formą (więcej online: http://chronofleks.nlp.ipipan.waw.pl/mod_analizy/; data dostępu: 12.08.2019). Podobne procedury zmian fleksyjnych i pisownianych przeprowadzono, przystosowując system Morfeusz do znakowania słownictwa z pierwszej połowy doby nowopolskiej w korpusie F19 (por. DerWojedowa i in., 2014).

System Chronofleks obejmuje również dane fleksyjne XX-wiecznej polszczyzny (na bazie Narodowego Korpusu Języka Polskiego, dalej: NKJP). Połączenie danych historycznych ze współczesnymi doprowadziło do skonstruowania zautomatyzowanego rejestru diachronicznych reguł fleksyjnych polszczyzny. Na stronie projektu można przeczytać, że w wyniku prowadzonych prac powstał „prototyp przekrojowego słownika fleksyjnego języka polskiego dostępnego przez Internet umożliwiający wizualizację zmian paradygmatów w czasie" (online: http://chronofleks.nlp.ipipan.waw.pl/podsumowanie; data dostępu: 31.07.2019).

System komputerowy Chronofleks składa się z dwóch modułów. Pierwszy z nich o nazwie „Paradygmaty” prezentuje zmienność wzorców fleksyjnych poszczególnych leksemów w czasie, drugi - „Wykresy” - pozwala na bardziej szczegółowe wyszukiwanie grup wyrazów ze względu na ich charakterystykę fleksyjną, umożliwia również przedstawienie danych $w$ postaci graficznej. Informacje na temat szczegółowych wyników projektu, jak przebieg procesu tworzenia reguł transkrypcyjnych, sposobów implementacji modułu analizy fleksyjnej i metod ujednoznaczniania fleksyjnego, a także opis zasad związanych ze znakowaniem tekstów można znaleźć na http://chronofleks.nlp.ipipan.waw.pl/. Ponadto strona zawiera objaśnienie procedury wdrożenia aplikacji Anotatornia 2, przykładowe zagadnienia językowe, które badać można na podstawie segmentów dostępnych w systemie Chronofleks, oraz dane bibliograficzne prac, które powstały na temat systemu Chronofleks lub z jego wykorzystaniem.

Zawartość danych $w$ systemie Chronofleks, podobnie jak w NKJP, liczona jest $w$ segmentach. Są to głównie słowa ortograficzne liczone 'od spacji do spacji', jednak w niektórych wypadkach segmenty mogą być krótsze. Sytuacja taka dotyczy końcówek aglutynacyjnych (np. [spał][eś], [często][by][śmy]), partykuł (np. [chcesz][li], [stój][że]), poprzyimkowych form zaimka -ń (np. [do][ń], [po][ń]), słów zawierających łącznik (np. [polsko][-][niemiecki]) oraz skrótów i inicjałów (zob. Przepiórkowskı, Buczyńskı, Wilk, 2011). Liczba danych językowych, z których korzysta Chronofleks w rozciągłości czasowej, to około 6,6 miliona segmentów dla XVII i XVIII wieku (KorBa), około 1 miliona - dla XIX wieku (F19) oraz 230 tysięcy dla polszczyzny XX-wiecznej (NKJP). Pozwala to mówić o niespełna 8-milionowym zbiorze segmentów z okresu 320 lat w wolnym dostępie. Do bazy systemu Chronofleks nie włączono wszystkich segmentów rejestrowanych przez oryginalne korpusy. Pominięto między innymi 1) segmenty odpowiadające interpunkcji, 2) segmenty oznaczone w korpusach 
jako język obcy oraz 3) leksemy nieodmienne. W przypadku NKJP zrezygnowano z danych $z$ tekstów, którym $w$ metryczce brakuje daty ich powstania. W konsekwencji baza systemu Chronofleks zawiera mniej segmentów niż całe korpusy, co jest zrozumiałe ze względu na cel i funkcję narzędzia. Liczbę segmentów w poszczególnych latach dostępnych w systemie przedstawiają niżej zamieszczone wykresy. Ręcznie znakowane dane prezentuje rysunek 1, z kolei rysunek 2 zawiera dane znakowane automatycznie. Należy zwrócić uwagę na brak danych z lat 1772-1830 (koniec KorBy, początek F19) oraz 1918-1945 (koniec F19, początek NKJP). Zakresy te są widoczne jako białe strefy na osi czasu.

Wybierz korpusy Korpus XIX w., Korba, Korba pojedyncza, NKJP1M

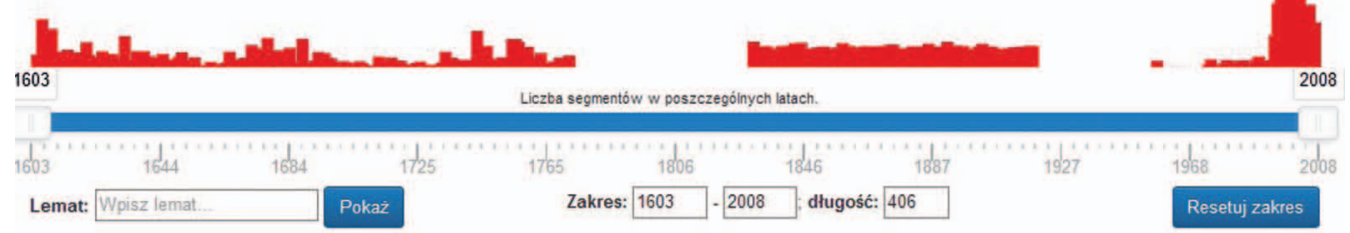

Rys. 1. Liczba segmentów znakowanych ręcznie dostępna w systemie Chronofleks w poszczególnych latach

Źródło: [online: http://chronofleks.nlp.ipipan.waw.pl/show/\#c=f19_m,korba_m,korba_p_m,nkjp_m\&yf=1603\&yt=20 08\&l=^^\&p=subst; data dostępu: 25.06.2020].

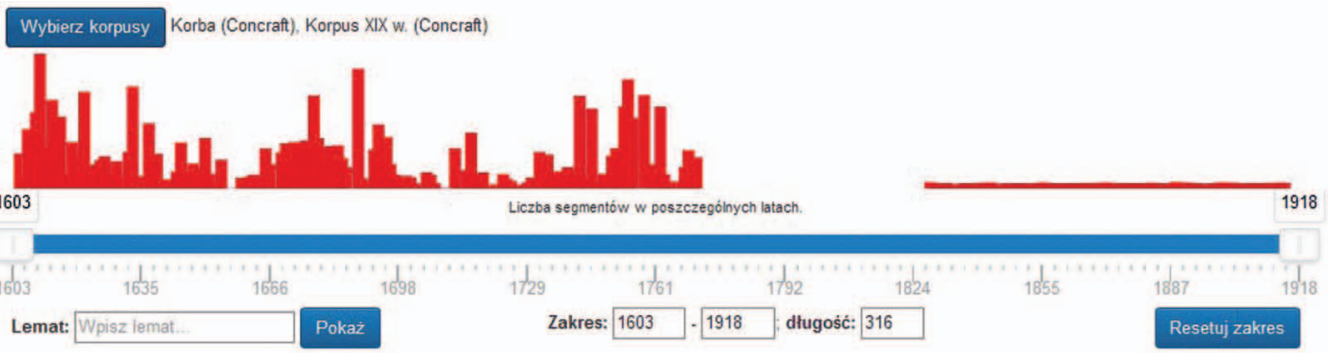

Rys. 2. Liczba segmentów znakowanych automatycznie dostępna w systemie Chronofleks w poszczególnych latach

Źródło: [online: http://chronofleks.nlp.ipipan.waw.pl/show/\#c=f19_a,korba_a\&yf=1603\&yt=1918\&l=^^\&p=subst; data dostępu: 25.06.2020].

Korzystanie z programu Chronofleks nie wymaga znajomości składni języka zapytań. System pokazuje historyczne dane językowe na podstawie uwspółcześnionej formy hasłowej wyszukiwanego wyrazu niezależnie od jego zapisu ortograficznego oraz wielkości pierwszej litery $w$ tekstach źródłowych ${ }^{4}$, na przykład komisja (zapis między rokiem 1650

4 Za pomocą systemu Chronofleks dokonuje się normalizacji zapisu transkrybowanego, z uwzględnieniem zapisu lematu. Jeśli więc postać w tekście brzmi „Bogiem”, ale przypisana jest do lematu "bóg”, to do systemu trafia znormalizowana postać „bogiem”. W tym sensie wyniki będą niezależne od wielkości pierwszej litery (bo segmenty „Bogiem” i „bogiem” dostaną taki sam zapis, pod warunkiem tylko, że oba mają przypisany lemat „bóg”). Jeśli jednak postać „Bogiem” ma przypisany lemat „Bóg” (wielką literą), to zapis znormalizowany zachowa wielką literę i będzie oddzielnie liczony (szczegółowe wyjaśnienie udzielone przez Komosińską). 
a 1918): commissiey, commissyi, komisja, komisją, komisje, komisji, komissja, komissya, komissye, komissyi, komisya, komisya, komisye, komisye, komisyi, komisyj, komisyja, komisyję, kommisij, kommisja, kommisjów, kommissii, kommissij, kommissja, kommissje, kommissjów, kommissya, kommissyi, kommissyiey, kommissyi (przykład za: Wolı́́skı i in., 2018). Dane na temat frekwencji współwystępujących w konkretnym przypadku gramatycznym końcówek fleksyjnych pozyskane za pomocą systemu umożliwiają ocenę zasięgu czasowego ich użycia.

Aby sprawdzić, jakie paradygmaty fleksyjne danego wyrazu rejestrują teksty z konkretnego przedziału czasowego, na przykład z lat 1603-1700, 1772-1830, należy w systemie sprecyzować okres wyszukiwania. Można również zawęzić pole obserwacji do jednego wybranego korpusu spośród trzech dostępnych w systemie, a także porównać dane z zasobów anotowanych ręcznie lub automatycznie. Rysunek 3 przedstawia porównanie danych na temat paradygmatów leksemu KOMISJA w zasobach KorBy, F19 i NKJP. Można zaobserwować, że w korpusie XVII i XVIII wieku $w$ dopełniaczu liczby pojedynczej nad formą komisjej (5) przeważa komisji (63), która to od wieku XIX staje się jedyną poświadczoną tekstowo formą tego przypadka, por. komisji (150 w F19; 34 w NKJP). Na przestrzeni wieków rywalizowały z sobą również końcówki biernika liczby pojedynczej. Zasób systemu Chronofleks dokumentuje, że $w$ tekstach KorBy znacznie częściej rejestrowane były formy z pierwotną końcówką - a, por. komisją (46) : komisję (5); w F19 ich liczba ulega zrównaniu, por. komisja (12) : komisje (18); NKJP dokumentuje całkowity zanik form fleksyjnych z końcówką - a, por. komisję (4). Obserwacja danych tekstowych biernika liczby pojedynczej leksemu KOMISJA pozwala na rekonstrukcję rozwoju tego przypadka dla pozostałych rzeczowników miękkotematowych rodzaju żeńskiego obcego pochodzenia, na przykład historia, litania, ewangelia.

\begin{tabular}{|c|c|c|c|c|c|c|c|c|}
\hline \multicolumn{3}{|c|}{ komisja subst, $f$ KorBa } & \multicolumn{2}{|c|}{ komisja subst, $f$} & F19 & \multicolumn{3}{|c|}{ komisja subst, f NKJP } \\
\hline & I. poj. & I. $\mathrm{mn}$. & & I. poj. & I. $\mathrm{mn}$. & & I. poj. & I. $\mathrm{mn}$. \\
\hline M. & komisja (65) & komisje (6) & M. & komisja (85) & komisje (20) & M. & komisja (27) & - \\
\hline D. & $\begin{array}{l}\text { komisjej (5) } \\
\text { komisji (63) }\end{array}$ & $\begin{array}{l}\text { komisyj (71) } \\
\text { komisji (3) }\end{array}$ & D. & komisji (150) & $\begin{array}{l}\text { komisyj (5) } \\
\text { komisjów (4) }\end{array}$ & D. & komisji (37) & komisji (1) \\
\hline c. & komisji (5) & - & c. & komisji (8) & - & c. & komisji (1) & - \\
\hline B. & $\begin{array}{l}\text { komisję (5) } \\
\text { komisją (46) }\end{array}$ & komisje (4) & B. & $\begin{array}{l}\text { komisję (18) } \\
\text { komisją (12) }\end{array}$ & komisje (2) & B. & komisję (4) & - \\
\hline N. & komisja (1) & komisjami (1) & N. & komisją (12) & - & N. & komisja (2) & - \\
\hline Msc. & $\begin{array}{l}\text { komisjej (1) } \\
\text { komisji (37) }\end{array}$ & komisjach (10) & Msc. & komisji (24) & komisjach (2) & Msc. & komisji (1) & komisjach (3) \\
\hline w. & - & - & w. & - & - & w. & - & - \\
\hline
\end{tabular}

Rys. 3. Wyniki wyszukiwania leksemu KOMISJA w zależności od korpusu (KorBa, F19, NKJP) Źródło: [online: http://chronofleks.nlp.ipipan.waw.pl/show/\#c=korba_a,korba_m,korba_p_m\&yf=1603\&yt=1772\&l=k omisja\&p=subst; data dostępu: 6.07.2020; http://chronofleks.nlp.ipipan.waw.pl/show/\#c=f19_a,f19_m\&yf=1918\&yt= 1918\&l=komisja\&p=subst; data dostępu: 6.07.2020; http://chronofleks.nlp.ipipan.waw.pl/show/\#c=nkjp_m\&yf=1957 $\& y \mathrm{t}=1957 \& \mathrm{l}=\mathrm{komisja} \& \mathrm{p}=$ subst; data dostępu: 6.07.2020].

Moduł o nazwie „Wykresy” pozwala na zobrazowanie w czasie omówionych wcześniej danych tabelarycznych. Dodatkowo umożliwia tworzenia serii zapytań o różnym stopniu szczegółowości. Funkcja ta pomocna jest zułaszcza w odniesieniu do końcówek równo- 
ległych, ponieważ pozwala obserwować ich wzajemną relację na przestrzeni lat. Dzięki modułowi można sporządzić listę 100 form tekstowych spełniających zadane warunki. Jeśli wyników wyszukiwania jest mniej, wtedy pojawią się wszystkie zarejestrowane segmenty, jeśli jest ich więcej - wyświetlą się losowo wybrane przykłady. Natomiast generowany wykres ujmuje wszystkie dane dostępne systemowi. W zależności od potrzeb można grupować je według częstotliwości wystąpień, ich liczby lub typów (liczby leksemów, od których tworzona jest obserwowana forma fleksyjna). Rysunek 4 przedstawia zmienność $w$ czasie form fleksyjnych celownika liczby pojedynczej rzeczowników rodzaju żeńskiego pogrupowanych w zależności od liczby wystąpień.

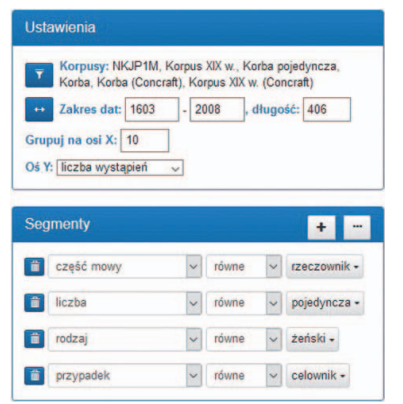

\begin{tabular}{lllll}
\hline lemat & cz. mowyy & orth & translit & fleksem \\
lutnia & subst & lutniej & lutniej & subst \\
\hline bracia & subst & braciej & Braciej & subst \\
\hline macica & subst & macicy & macicy & subst \\
\hline fortuna & subst & fortunie & Fortunie & subst \\
\hline akademia & subst & akademiej & Akádảmiey & subst \\
\hline Katarzyna & subst & Katarzynie & Katharzynie & subst \\
\hline danina & subst & daninie & daninie & subst \\
\hline Jadwiga & subst & Jadwidze & ladwidze & subst \\
\hline kartana & subst & kartanie & kartanie & subst \\
\hline jejmość & subst & jejmości & leymośći & subst \\
\hline Karolina & subst & Karolinie & Karolinie & subst \\
\hline ściana & subst & ścianie & ściánié & subst \\
\hline armata & subst & armacie & ármacie & subst \\
\hline
\end{tabular}

\begin{tabular}{|c|c|c|}
\hline liczba & orzypa & k rodzaj \\
\hline sg & dat & 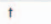 \\
\hline $\mathrm{sg}$ & dat & f \\
\hline $\mathrm{sg}$ & dat & $f$ \\
\hline sg & dat & $f$ \\
\hline sg & dat & $f$ \\
\hline sg & dat & $f$ \\
\hline sg & dat & $f$ \\
\hline sg & dat & $f$ \\
\hline $\mathrm{sg}$ & dat & $f$ \\
\hline sg & dat & $f$ \\
\hline sg & dat & $f$ \\
\hline sg & dat & $f$ \\
\hline $\mathrm{sg}$ & dat & $f$ \\
\hline
\end{tabular}

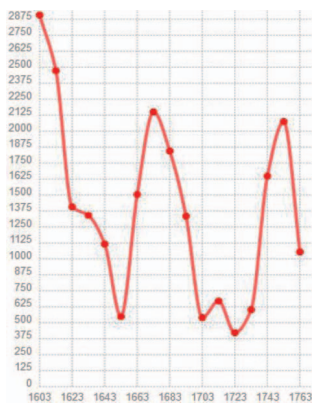

Rys. 4. Zapytanie o końcówki C. I. poj. rzeczowników r. żeńskiego wraz z wynikami tego wyszukiwania $w$ postaci listy przykładowych rekordów i wykresu zmienności danych w czasie

Źródło: [online: http://chronofleks.nlp.ipipan.waw.pl/chart/\#c=f19_m,korba_m,korba_p_m,nkjp_m\&yf=1603\&yt=176 $3 \& \mathrm{z}=10 \& \mathrm{y}=\operatorname{seg} \& \mathrm{r}=1 \& \mathrm{rt}=$ Reszta\&srs=Segmenty;3_0_0;5_0_0;7_0_3;6_0_2; data dostępu: 6.07.2020].

\section{System Chronofleks - badania}

Poświadczenia tekstowe zjawisk językowych wykorzystywane są na zajęciach kursowych z morfologii historycznej oraz na wykładach z historii języka. Również podczas laboratoriów z leksykografii rozwijane są umiejętności związane z dokumentacją danych gramatycznych i ich analizą. Chronofleks stanowi narzędzie, które może ułatwić studentowi zdobywanie wiedzy, a także wzmocnić jego motywację do samodzielnej nauki. Twórcy systemu zaproponowali wykorzystanie stworzonego przez siebie internetowego narzędzia do obserwacji zaniku w XVII i XVIII wieku tzw. form niezłożonych przymiotnika, liczby podwójnej oraz pojawienia się wykładników fleksyjnych rodzaju męskoosobowego rzeczowników (online: http://chronofleks.nlp.ipipan.waw.pl/chronofleks; data dostępu: 21.08.2019). Tematów do badań jest bardzo wiele. Funkcjonowanie w uzusie tzw. reguły Kopczyńskiego, dystrybucja końcówek dopełniacza liczby pojedynczej rzeczowników rodzaju męskiego oraz frekwencja końcówki w 1. osobie liczby mnogiej czasowników to przykładowe zagadnienia, których udokumentowania można szukać w zasobach dostępnych systemowi Chronofleks. Kolejne akapity zawierają opracowanie tych zagadnień za pomocą funkcji dostępnych w systemie. 
3.1. Rozwój końcówek fleksyjnych narzędnika i miejscownika liczby pojedynczej przymiotników rodzaju męskiego i nijakiego (tzw. reguła Kopczyńskiego)

Zjawiskiem doby średniopolskiej było mieszanie się końcówek narzędnika i miejscownika liczby pojedynczej rodzaju męskiego oraz nijakiego, zarówno przymiotników, jak i zaimków. Zadaniem studenta może być odtworzenie reguł fleksyjnych dla wskazanych przypadków gramatycznych z wykorzystaniem systemu Chronofleks. Ustawienie odpowiednich parametrów wyszukiwania w module „Wykresy” pozwala na generowanie wykresów przedstawiających zmienność $w$ czasie liczby obu przymiotnikowych końcówek.

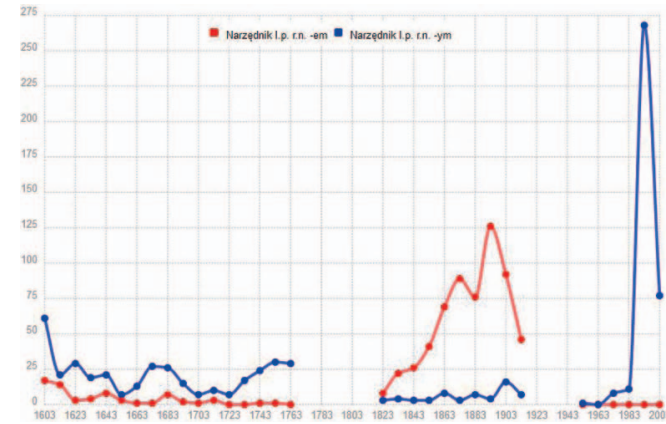

Rys. 5a. Wizualizacja rozwoju końcówki N. przymiotników rodzaju nijakiego w l. poj.

Źródło: [online: http://chronofleks.nlp.ipipan.waw.pl/ chart/\#c=f19_m,korba_m,korba_p_m,nkjp_m\&yf =1603 $\& y t=2008 \& \mathrm{r}=10 \& \mathrm{y}=\mathrm{seg} \& \mathrm{r}=1 \& \mathrm{rt}=$ Reszta $\& \mathrm{srs}=$ Segmen ty;3_0_1;5_0_0;7_0_4;6_0_4;0_4_em; data dostępu: 6.07.2020].

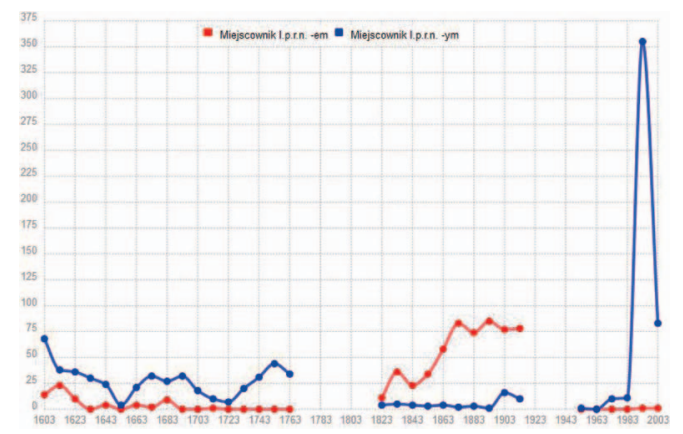

Rys. 5c. Wizualizacja rozwoju końcówki Msc. przymiotników rodzaju nijakiego w l. poj.

Źródło: [online: http://chronofleks.nlp.ipipan.waw.pl/ chart/?\#c=f19_m,korba_m,korba_p_m,nkjp_m\&yf $=160$ $3 \& \mathrm{yt}=2008 \& \mathrm{r}=10 \& \mathrm{y}=\mathrm{seg} \& \mathrm{r}=1 \& \mathrm{rt}=$ Reszta $\& \mathrm{srs}=$ Segme nty;3_0_1;5_0_0;7_0_4;6_0_5;0_4_em; data dostępu: 6.07.2020].

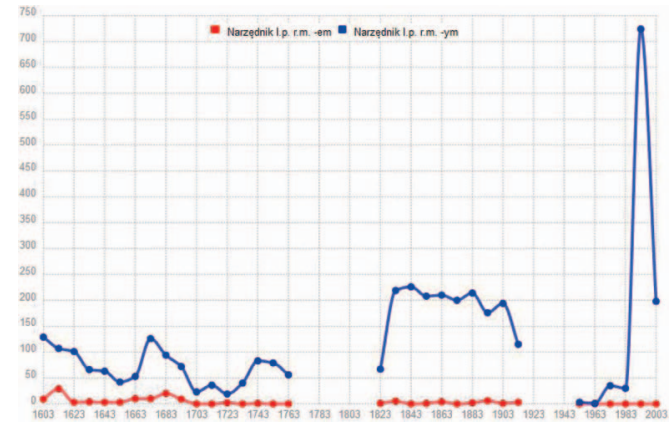

Rys. 5b. Wizualizacja rozwoju końcówki N. przymiotników rodzaju męskiego w l. poj.

Źródło: [online: http://chronofleks.nlp.ipipan.waw.pl/ chart/?\#c=f19_m,korba_m,korba_p_m,nkjp_m\&yf $=160$ $3 \& \mathrm{yt}=2008 \& \mathrm{r}=10 \& \mathrm{y}=\mathrm{seg} \& \mathrm{r}=1 \& \mathrm{rt}=$ Reszta\&srs=Segmen ty;3_0_1;5_0_0;7_0_0;6_0_4;0_4_ym; data dostępu: 6.07.2020].

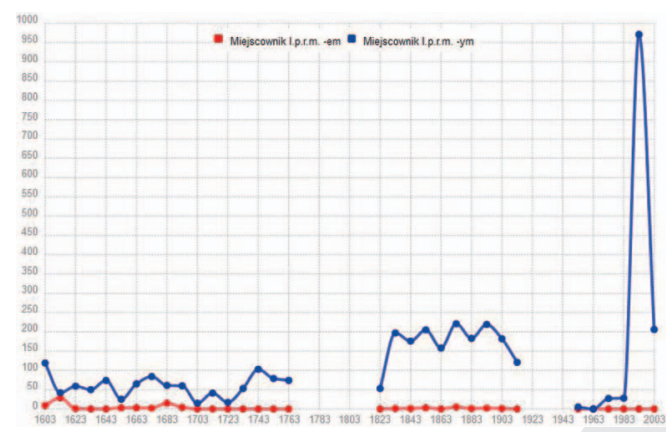

Rys. 5d. Wizualizacja rozwoju końcówki Msc. przymiotników rodzaju męskiego w l. poj.

Źródło: [online: http://chronofleks.nlp.ipipan.waw.pl/ chart/?\#c=f19_m,korba_m,korba_p_m,nkjp_m\&yf $=160$ $3 \& \mathrm{yt}=2008 \& \mathrm{r}=10 \& \mathrm{y}=\mathrm{seg} \& \mathrm{r}=1 \& \mathrm{rt}=$ Reszta\&srs $=$ Segmen ty;3_0_1;5_0_0;7_0_0;6_0_5;0_4_em; data dostępu: 6.07.2020].

Na rysunkach 5a-5d widoczna jest w latach 1603-1763 podobna odpowiedniość, która zachodzi między liczbą form przymiotnikowych z końcówką -em oraz -ym. Dotyczy to zarówno form tekstowych narzędnika, jak i miejscownika; przeważa użycie końców- 
ki -ym. Sytuacja taka jest skutkiem zjawisk fonetycznych związanych z zanikiem iloczasu w polszczyźnie. Podwyższenie artykulacyjne samogłoski $e$ spowodowało zbliżenie brzmienia końcówki - ém do -ym, a tym samym rozpoczęło mieszanie się tych końcówek. Teksty barokowe dowodzą, że użycie końcówki -ym (pierwotnej w obu rodzajach dla narzędnika) lub -em (pierwotnej $w$ obu rodzajach dla miejscownika) zależało często od upodobań pisarza. Zgodnie z postulatami Piotra Statoriusa-Stojeńskiego, Walentego Szylarskiego i Onufrego Kopczyńskiego w drugiej połowie XVIII wieku wprowadzono normę różnicującą końcówki tych przypadków według kryterium rodzaju, w miejsce pierwotnego przypadka (DŁugosz-Kurczabowa, Dubisz, 2001: 246). Widoczna na rysunkach 5a i 5c w latach 1823-1923 znaczna przewaga form z końcówką - em dla rodzaju nijakiego (kolor czerwony) oraz przewaga $w$ tym samym okresie form $z$ końcówką - ym dla rodzaju męskiego widoczna na rysunkach 5b i 5d (kolor niebieski) jest potwierdzeniem funkcjonowania reguł postulowanych przez grono gramatyków. Wspomniane arbitralnie wprowadzone przepisy fleksyjne zostały z czasem zniesione. Polska Akademia Umiejętności uznała je za sprzeczne z rozwojem historycznym oraz niezgodne z uzusem językowym. Wynik reformy ortograficznej z 1936 roku można odczytać z każdego z zaprezentowanych wykresów. Widoczny na rysunkach 5a-5d pik koloru niebieskiego wraz z jednoczesnym wypłaszczeniem linii $w$ kolorze czerwonym to ilustracja przepisów wprowadzających jedną końcówkę -ym w obu przypadkach i obu rodzajach.

Student może spróbować dokonać rekonstrukcji etapów rozwoju form narzędnika i miejscownika w wyniku samodzielnej pracy z systemem. W ten sposób tradycyjna podająca metoda pracy zostanie zastąpiona podejściem problemowym do zagadnienia. Zaproponowana postawa badawcza rozwija produktywne myślenie i krytycyzm poznawczy, ponadto pozwala zwiększyć motywację uczenia się studenta i sprzyja utrwalaniu jego wiedzy. Prócz tego rozwijane są takie ogólne umiejętności, jak sztuka prowadzenia obserwacji oraz nauka wyciągania wniosków. Cyfrowe narzędzia dają możliwość połączenia kształcenia historycznojęzykowego z poszerzaniem ogólnych zdolności intelektualnych studenta.

Podobne ćwiczenia można przeprowadzić na podstawie analiz form narzędnika liczby mnogiej w rodzaju męskoosobowym i niemęskoosobowym. Działanie tzw. reguły Kopczyńskiego student może sprawdzić także na materiale zaimków.

3.2. Kształtowanie się rodzaju męskożywotnego na podstawie form dopełniacza liczby pojedynczej rzeczowników

Podręczniki do gramatyki historycznej (Klemensiewicz, 1952; Stieber, 1969; Rospond, 1971; Dtugosz-Kurczabowa, Dubisz, 2001) informują o czterech prasłowiańskich końcówkach dopełniacza liczby pojedynczej deklinacji męskiej. Dwie z nich $(-e,-i)$ wyszły z użycia jeszcze $w$ dobie przedpiśmiennej, natomiast pozostałe dwie $(-a,-u)$ konkurują z sobą od czasów najdawniejszych. Na podstawie danych ekstrahowanych ze znakowanych fleksyjnie korpusów system Chronofleks daje możliwość porównania frekwencji rywalizujących końcówek - $u$ oraz - $a$. Ekspansywność końcówki - $u$ (wśród rzeczowników twardotematowych) odczytać można z wykresu na rysunku 6 (kolor czerwony). Znaczny spadek jej częstotliwości związany jest z rozwojem kategorii żywotności rzeczowników męskich. Pogłębiona obserwacja wyników wyszukiwania systemu Chronofleks o analizę wartości semantycznej materiału językowego, który system wyekstrahował z korpusów, pozwoli wykazać, że na- 
stąpiła specjalizacja końcówki - a do rzeczowników żywotnych (wyjątek wołu, bawołu). Wariantywność końcówki - $a$ lub - $u$ to zaś cecha rzeczowników nieżywotnych.

Rysunek 7 przedstawia frekwencję form stoła (czerwona linia) i stołu (linia niebieska) $w$ rozciągłości czasowej. Zauważalne jest w latach 1603-1733 współwystępowanie form dopełniacza z pierwotną końcówką - $a$ oraz wtórną - $u$ (historycznie ograniczoną do nielicznej deklinacji męskiej ŭ-tematowej). Z biegiem lat stabilizuje się jedna końcówka - $u$ dla tego leksemu. System Chronofleks nie znajduje w dostępnych mu zasobach korpusowych poświadczeń tekstowych formy stoła po 1740 roku. Dokładna liczba poświadczeń wybranej formy fleksyjnej $w$ tekstach $z$ danego roku wyświetlana jest na żółtym polu po ustawieniu kursora $w$ odpowiednim miejscu na krzywej wykresu (np. rys. 7).

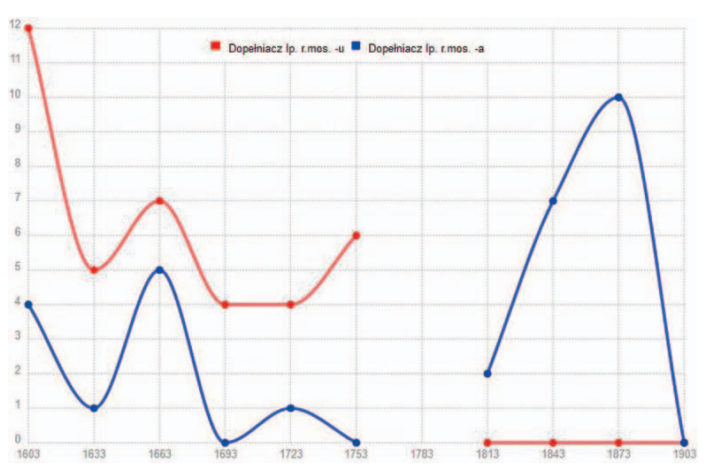

Rys. 6. Wizualizacja liczby wystąpień końcówek $-u$ oraz - $a$ w D. I. poj. rzecz. mż. w latach 1603-1903 Źródło: [online: http://chronofleks.nlp.ipipan.waw.pl/char $\mathrm{t} / \# \mathrm{c}=\mathrm{f19}$ _m,korba_m,korba_p_m,nkjp_m\&yf $=1603 \& \mathrm{yt}=19$ $03 \& \mathrm{r}=10 \& \mathrm{y}=\mathrm{seg} \& \mathrm{r}=1 \& \mathrm{rt}=$ Reszta\&srs=Segmenty;0_0_!Ser ia\%201;0_0_sto\%C5\%82a;0_0_sto\%C5\%82u; data dostępu: 6.07.2020]

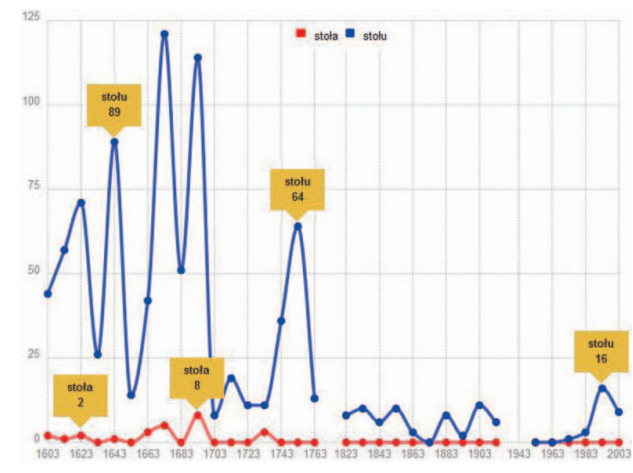

Rys. 7. Wizualizacja liczby wystąpień form D. I. poj. stołu oraz stoła w latach 1603-2008 Źródło: [online: http://chronofleks.nlp.ipipan.waw. $\mathrm{pl} /$ chart/\#c=f19_a,f19_m,korba_a,korba_m,korba_ p_m,nkjp_m\&yf $=1603 \& y \mathrm{t}=2008 \& \mathrm{r}=10 \% \mathrm{y}=\mathrm{rel} \& \mathrm{r}=$ $1 \& \mathrm{rt}=$ Reszta\&srs=Segmenty;0_0_!Seria\%201;0_0_ sto $\%$ C5\%82u;0_0_sto\%C5\%82a; data dostępu: 6.07.2020].

Rozwinięciem omówionych zagadnień może być próba odnalezienia dodatkowych kryteriów semantycznych, które decydują obecnie o dystrybucji obu końcówek wśród rzeczowników męskich nieżywotnych, czyli scharakteryzowanie na bazie danych z korpusu NKJP końcówki - a jako dopełniacza nazw narzędzi, sprzętów, naczyń, miar, wag, liczb, nazw miesięcy, marek samochodów (np. śrubokręta, telewizora, komputera, słoika, metra, kilograma, kwadransa, kwietnia, opla); nazw części ciała, tańców, papierosów, gier, owoców, grzybów (np. nosa, zęba, walca, camela, tenisa, banana, borowika); natomiast końcówki - $u$ jako dopełniacza rzeczowników pochodzenia obcego (internacjonalizmów), nazw abstrakcyjnych, a także skrótowców (np. teatru, weekendu, bólu, śmiechu, cukru, PAN-u, LOT-u).

Fakultatywność występowania obu końcówek, które student rozpoznaje jako zjawisko współczesnej polszczyzny (np. fotela//fotelu, krawata//krawatu), można prześledzić $w$ tekstach z XVII wieku, w których notuje się formy zarówno wieka, obiada, dwora, jak i wieku, obiadu, dworu. Polszczyzna najnowsza pozwala na wyzyskanie obocznych końcówek dopełniacza do sformalizowania różnic znaczeniowych, na przykład przypadku 'losu' : przypadka 'formy gramatycznej', strachu 'uczucie' : stracha 'na wróble', zbiega 'uciekającego' : zbiegu 'okoliczności', geniusza 'człowieka genialnego' : geniuszu ‘wybitnego talentu', postu 'wstrze- 
mięźliwość od jedzenia' : posta ‘wiadomości na forum internetowym' (JADAcKA, 2005; Markowski, 2005). Proponowane połączenie wiadomości z zakresu morfologii historycznej z zagadnieniami gramatyki opisowej współczesnej polszczyzny i kultury języka polskiego może pomóc studentowi $w$ zrozumieniu celu nauczanych treści historycznojęzykowych oraz wzmocnić $w$ nim poczucie holistycznego programu studiów.

\subsection{Rozwój końcówki fleksyjnej 1. osoby liczby mnogiej czasowników trybu oznajmującego}

W 1. osobie liczby mnogiej odmiany czasownika mówimy dziś o końcówkach -emy, -imy, -my. Jednocześnie obecne są w polszczyźnie rzadsze formy, które kończą się na -m, por. przejdziem, będziem, rzucim. Pytanie o frekwencję tych końcówek może stanowić dla studenta zadanie do rozwiązania za pomocą systemu Chronofleks. Podręczniki do gramatyki historycznej zawierają wyjaśnienie ich historii. Zgodnie z prawami głosowymi wykształciła się $w$ polszczyźnie końcówka fleksyjna na bazie psł. ${ }^{*}-m ヶ>$ pol. - $m$ i psł. przyrostka tematycznego lub jego elementu samogłoskowego. Zakończenie takie dominowało $w$ okresie staropolskim, często notowane było również $w$ tekstach doby średniopolskiej. Widać jednak, że nowe zakończenie ukształtowane pod wpływem zaimka 1. osoby liczby mnogiej my, które najpierw stało się dominantą w czasownikach atematycznych (z uwagi na tożsamość formy 1. os. I. poj. i l. mn.), a następnie w pozostałych paradygmatach stosowanych $w$ języku literackim (tj. pisanej odmianie języka ogólnopolskiego) wcześnie wyparło końcówkę pierwotną. W okresie średniopolskim końcówkami podstawowymi są już - emy, -imy, - my, choć przez cały ten okres, a nawet w XIX wieku, w tekstach współwystępują - em, -im, -m (m.in. utwory Jana Kochanowskiego, Ignacego Potockiego, Wespazjana Kochowskiego, Stanisława Staszica, Józefa Wybickiego, Juliusza Słowackiego, Marii Konopnickiej), które to końcówki otrzymują status końcówek regionalnych, następnie gwarowych oraz artystyczno-stylizacyjnych. Stosowane są dziś głównie w tekstach literackich jako przejaw archaizacji, dialektyzacji czy hieratyczności stylu. Jako gwarowe notowane są na terenie Polski północnej. Na rysunku 8a poszczególne krzywe odpowiadają częstości występowania (frekwencji) tekstowych form 1. osoby liczby mnogiej czasowników: formy koniugacyjne z zakończeniem pierwotnym - em, -im,-m (linia czerwona), zakończenie wtórne - emy, -imy, -my (linia niebieska). Z wykresu wynika, że formy koniugacyjne z zakończeniem pierwotnym już od początku XVII wieku były nieliczne. Ich bogatszą reprezentację notują teksty z okresu walk z imperium osmańskim (1683), z najazdu tureckiego na Rzeczpospolitą (1688), utwory drukowane podczas powstania krakowskiego (1843), powstania wielkopolskiego i Wiosny Ludów (1848-1849). Przykładowe rekordy form starszych zawiera lista zamieszCzona na rysunku $8 \mathrm{~b}$.

Z dokumentacji tekstowych wynika, że największą liczbę form czasownikowych $w$ 1. osobie liczby mnogiej rejestrowano $w$ drugiej połowie XIX wieku. Wyniki wyszukiwania pozwalają łączyć zachowania językowe Polaków z wydarzeniami historycznymi. Czas powstania styczniowego w Królestwie Polskim w 1863 roku wymagał pisania utworów o charakterze apelów i odezw. 


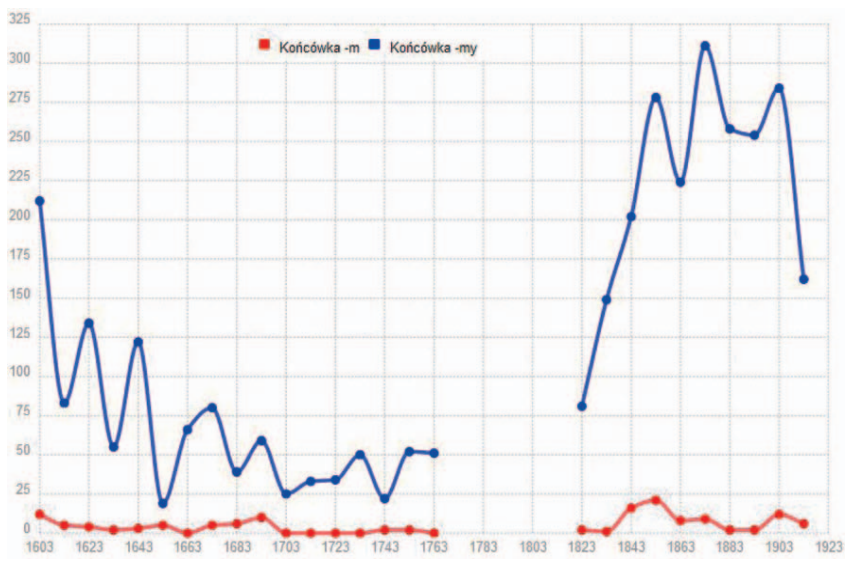

Rys. 8a. Wizualizacja zakończeń -m, -my 1 os. I. mn. czasowników

Źródło: [online: http://chronofleks.nlp.ipipan.waw.pl/chart/\#c= f19_a,f19_m,korba_a,korba_m,korba_p_m,nkjp_m\&yf $=1603 \& y$ $\mathrm{t}=2008 \& \mathrm{~s}=10 \& \mathrm{y}=\mathrm{rel} \& \mathrm{r}=0 \& \mathrm{rt}=\mathrm{Reszta} \& \mathrm{srs}=\mathrm{Segment} \mathrm{y}$ !Seria $\% 20$ $1 ; 3 \_0 \_3 ; 5 \_0 \_2 ; 8 \_0 \_0 ; 0 \_4 \_\mathrm{m}$ !Seria\%202;3_0_3;5_0_2;8_0_0;0_4_ym; data dostępu: 6.07.2020].

\begin{tabular}{|c|c|}
\hline \multicolumn{2}{|c|}{ Przykładowe rekordy: } \\
\hline orth & orth \\
\hline ważym & uprzedzamy \\
\hline nazwiem & dokażemy \\
\hline musielim & pytamy \\
\hline siedziem & widzimy \\
\hline wierzym & stanęliśmy \\
\hline wierzym & wspomniemy \\
\hline pomieścim & żądaliśmy \\
\hline stoim & zrucamy \\
\hline pędzim & traktujemy \\
\hline siędziem & wróżymy \\
\hline wywodzim & zdziwimy \\
\hline widzim & zaznaczyliśmy \\
\hline
\end{tabular}

Rys. 8b. Przykładowe formy 1 os. l. mn. czasowników

Źródło: [online: http://chronofleks.nlp. ipipan.waw.pl/chart/\#c=f19_a,f19_m,k orba_a,korba_m,korba_p_m,nkjp_m\& $y f=1603 \& y t=2008 \& x=10 \& y=r e l \& r=0$ $\& r t=$ Reszta\&srs=Segmenty!Seria $\% 20$ 1;3_0_3;5_0_2;8_0_0;0_4_m!Seria\%20 2;3_0_3;5_0_2;8_0_0;0_4_ym; data dostępu: 6.07.2020].

Cenne byłoby uzupełnienie danych systemu o okres wcześniejszy (sprzed XVII w.), co pozwoliłoby odpowiedzieć na pytanie: Od kiedy rozpoczyna się eliminacja form z zakończeniem -m? Możliwości takie daje włączenie do zasobów systemu Chronofleks efektu prac prowadzonych od 2018 roku w Instytucie Języka Polskiego Polskiej Akademii Nauk $w$ Krakowie w ramach grantu badawczego Baza leksykalna średniowiecznej polszczyzny (do 1500 roku). Fleksja. Celem przedsięwzięcia jest interpretacja gramatyczna słownictwa tekstów doby staropolskiej (przyporządkowanie leksemu do danej części mowy, katalog form fleksyjnych poświadczonych $w$ materiale źródłowym, przykładowe cytaty ilustrujące użycie formy w tekście), por. https://ijp.pan.pl/nauka-i-badania/projekty/projekty-realizowane/baza-leksykalna-sredniowiecznej-polszczyzny-do-1500-roku-fleksja/ (data dostępu: 30.01.2020). Wymagałoby to zapewne kolejnych prac techniczno-inżynieryjnych, jednak próby zastosowania automatycznej anotacji morfosyntaktycznej tekstów do 1500 roku za pomocą tagera TaKIPI zostały już podjęte (por. Eder, KlapPer, KoŁodziej, 2015). Obecnie zainteresowany student może skorzystać z zamieszczonych na stronie Słownika polszczyzny XVI wieku (http://sprui.edu.pl/wersja-cyfrowa/) paradygmatów czasowników. W zakładce „Dodatki” znajduje się elektroniczna wersja (pliki PDF) opracowania Krystyny Wilczewskiej Czasowniki w "Słowniku polszczyzny XVI wieku” (odmiana i słowotwórstwo) (data dostępu: 30.01.2020).

Aktualne funkcje systemu Chronofleks nie dają możliwości podglądu szczegółowych danych na wykresie, tzn. system nie informuje, które z form notowane są w poszczególnych latach (dekadach, przedziałach czasowych) widocznych na wykresie. Podobnie jest z charakterystyką autorów, którzy w wybranym przedziale czasu używali konkretnej formy fleksyjnej. Funkcje te mogłyby okazać się przydatne dla osób zainteresowanych studiami z zakresu 
językowego obrazu świata. Jak dowodzą wyniki różnych językowych prac badawczych, wysoka frekwencja jakiejś formy może zupełnie nie odpowiadać jej popularności, a być jedynie upodobaniem językowym jednego autora lub wynikiem niezrównoważenia tekstów z danego okresu w korpusie. Wprowadzenie możliwości ustalenia informacji na temat źródła paradygmatów mogłoby zapobiec formułowaniu nie do końca trafnych wniosków.

W podsumowaniu opinii na temat użytkowania systemu Chronofleks i jego technicznych możliwości można dodać, że brakuje $w$ nim funkcji pozwalającej na zapisanie wygenerowanego wykresu. Przydatna byłaby również możliwość wykonania kopii wyników wyszukiwania w postaci dokumentu Excel. Ponadto, jako mało intuicyjny ocenić można sposób tworzenia serii wybranych grup fleksyjnych lub form wyrazowych na bazie konkretnego segmentu w module „Wykresy”, gdzie należy zawsze ustalić nadrzędny zakres wyszukiwania jako segment, w którego zakresie możliwe jest dopiero tworzenie serii o bardziej szczegółowych parametrach zapytania. Można pomyśleć także o integracji systemu z hasłami słowników historycznych powstałych na bazie korpusów, z których Chronofleks korzysta. W przypadku braku znajomości semantyki jakiegoś wyrazu, prócz oglądu paradygmatu odmiany, możliwe byłoby poznanie jego znaczeń i przejrzenie użyć w tekstach, por. apanaż, sęstwo, marglować. Realizacji takich działań sprzyja ciągły rozwój elektronicznych prac korpusowych i słownikarskich.

\section{Zakończenie}

Przeprowadzone badania językowe z wykorzystaniem możliwości systemu Chronofleks dowodzą, że jest to narzędzie, które pozwala na samodzielną obserwację zagadnień fleksyjnych. Automatyczne wyszukiwanie działa sprawnie. System w krótkim czasie wyświetla zadane rekordy. Wyniki wyszukiwania można zwizualizować w przejrzysty sposób. Ponadto system Chronofleks wyróżnia dostęp do informacji ilościowej, co umożliwia badanie nie tylko tego, jakie formy danych leksemów są potwierdzone, ale też, ile jest tych potwierdzeń i jak są one rozłożone w czasie. Praca z systemem ułatwia przyswajanie wiedzy, a możliwość opracowania zagadnień językowych na bazie autentycznych danych sprzyja wyciąganiu prawidłowych wniosków. Chronofleks pozwala realizować model dydaktyczny nastawiony na samokształcenie. Umożliwia studentowi korzystanie z posiadanych sprawności cyfrowych, daje możliwość ich wyćwiczenia i spożytkowania do zdobycia nowych informacji.

$\mathrm{Na}$ temat elektronicznych zasobów językowych można przeczytać w przewodniku Patrycji PAtKı i Agaty Kwaśnickiej-Janowicz (2017). W ramach przeglądu zasobów cyfrowych w publikacji przeznaczonej dla „studentów kierunków humanistycznych, magistrantów, doktorantów, pracowników naukowych, a także miłośników języka polskiego, którzy od podstaw poznają zasoby elektroniczne oraz sposoby i możliwości ich eksploatowania" (PAtKA, KWAŚNICKA-JANOWICZ, 2017: 14) przedstawione zostały zarówno biblioteki cyfrowe, bazy skanów, słowniki, korpusy i kartoteki cyfrowe oraz kompendia elektroniczne. Zbiór ten poszerza i uzupełnia o narzędzia stworzone przez konsorcjum CLARIN-PL oraz mniejsze projekty, typu MoncoPL, Korpusomat, Wirtualne Laboratorium Transkrypcji, Jasnopis artykuł Beaty Dudy i Karoliny LısczyK (2018). Autorki uważają, że narzędzia oraz aplikacje 
internetowe „mogą okazać się cennym wsparciem w dydaktyce akademickiej i pozwolą uatrakcyjnić zajęcia kursowe skierowane do studentów polonistyki" (DudA, LisczYK, 2018: 144).

Rozwój technologii sprzyja powstawaniu coraz nowszych narzędzi przeznaczonych do tego typu pracy dydaktycznej i naukowej. Nie wydaje się jednak, by dokonywała się technologizacja nauki, której należałoby się obawiać, jak głoszą pesymiści skoku technologicznego (por. Wobalıs, 2017). Nauczanie akademickie jest systemem, któremu nie zagraża napór nowych technologii i narzędzi cyfrowych. Rozwijające się media elektroniczne zdają się wręcz wzmacniać jeszcze rolę, jaką przypisuje się kształceniu akademickiemu. Jak podsumowuje Mirosław Wobalis:

[...] taki model edukacji jest właśnie $w$ dzisiejszych czasach paradoksalnie najbardziej potrzebny - stanowi bowiem jedną z kilku (wraz z kulturą wysoką, dobrym wychowaniem, tradycyjnymi normami społecznymi i wartościami humanistycznymi) ważną przeciwwagę dla świata opisanego w wizjach pesymistów, ważną kotwicę gwarantującą nam kontakt z przeszłością, bez której ani teraźniejszość, ani przyszłość nie mają racji bytu. [...] [t]o szkoły i uniwersytety, ze szczególnym uwzględnieniem przedmiotów szkolnych oraz kierunków akademickich związanych z kształceniem humanistycznym, powinny stanowić dla zmęczonych cyber-wędrowców oazę skupienia, koncentracji, refleksji, selekcji i żmudnej analizy.

WoBALIS, 2017: 443

Zajęcia prowadzone klasycznymi metodami kształcenia uzupełnione narzędziami wykorzystującymi technologie informacyjne powinny zaspokoić oczekiwania odbiorców oferty akademickiej. Zespolenie tradycji z nowoczesnością niesie wiele korzyści zarówno dla studentów, jak i nauczycieli, dla których innowacyjne rozwiązania stanowić mogą źródło satysfakcji dydaktycznej wynikającej z zadowolenia studenta z formy przebiegu kursu. Nowe technologie powinny zatem wesprzeć dydaktykę $w$ murach uczelni, a nie ją zastąpić. Redaktorka książki Perspektywy zmian w praktyce kształcenia akademickiego, Dorota Ciechanowska, zauważa we wprowadzeniu:

Współczesny uniwersytet stał się areną ścierania się tradycyjnych i nowoczesnych poglądów. [...] Studia przestały być elitarne $w$ rozumieniu, jakie nadawano im jeszcze dwadzieścia lat temu. Jakość kształcenia akademickiego rozpatrywać dziś należy w perspektywie oczekiwań studentów. A oczekują oni dobrego, merytorycznego i praktycznego przygotowania do zawodu, wiedzy szybkiej i studiowania bardziej skoncentrowanego na odpowiedziach niż pytaniach.

CIECHANOWSKA, 2014: 7

Uczymy nowe pokolenie, spróbujmy zatem uczyć je w nowy sposób. 


\section{Słowniki}

Czasowniki w „Słowniku polszczyzny XVI wieku” (odmiana i słowotwórstwo). WiLCzEWSKA K., oprac. [online: https://sprvi.edu.pl/media/uploads/dodatki/03_a_1.pdf; data dostępu: 30.01.2020].

Słownik gramatyczny języka polskiego. SAlonı Z., red. [online: http://sgjp.pl/leksemy; data dostępu: 21.08.2019].

SPXVI - Słownik polszczyzny XVI wieku [online: http://sprui.edu.pl/wersja-cyfrowa/; data dostępu: 7.06.2019].

\section{Korpusy}

Baza leksykalna średniowiecznej polszczyzny (do 1500 roku). Fleksja - [online: https://ijp.pan.pl/ nauka-i-badania/projekty/projekty-realizowane/baza-leksykalna-sredniowiecznej-polszczyzny-do1500-roku-fleksja/; data dostępu: 7.06.2019].

Chronofleks [online: http://chronofleks.nlp.ipipan.waw.pl/; data dostępu: 21.08.2019].

[online: http://chronofleks.nlp.ipipan.waw.pl/mod_analizy; data dostępu: 7.06.2019].

[online: http://chronofleks.nlp.ipipan.waw.pl/podsumowanie; data dostępu: 31.07.2019].

[online: http://chronofleks.nlp.ipipan.waw.pl/chronofleks; data dostępu: 21.08.2019].

[online: http://zil.ipipan.waw.pl/Chronofleks; data dostępu: 7.06.2019].

F19 - Korpus polszczyzny 1830-1918 [online: http://www.f19.uw.edu.pl; data dostępu: 21.08.2019].

KorBa - Elektroniczny korpus tekstów polskich z XVII i XVIII wieku (do 1772 r.) [online: https://www. korba.edu.pl/query_corpus/; data dostępu: 21.08.2019].

Morfeusz - [online: http://morfeusz.sgjp.pl; data dostępu: 21.08.2019].

NKJP - Narodowy Korpus Języka Polskiego [online: http://nkjp.pl/; data dostępu: 7.06.2019].

\section{Literatura}

BAtorskı D., 2013: Polacy wobec technologii cyfrowych - uwarunkowania dostępności i sposobów korzystania. „Contemporary Economics” VII, s. 317-341 [online: www.ce.vizja.pl/en/+downloadpdf/uolume/7/issue/3.1/id/295; data dostępu: 20.08.2019].

CiechanowsKa D., red., 2014: Perspektywy zmian w praktyce kształcenia akademickiego. Szczecin.

CuBAN L., 2001: Oversold and Underused. Computers in the Classroom. Cambridge.

Derwojedowa i in., 2014: Derwojedowa M., Kieraś W., Skowrońska D., Wotosz R.: Współczesne narzędzia leksykograficzne a analiza tekstów dawniejszych. „Polonica” XXXIV, s. 21-27.

DŁugosz-Kurczabowa K., Dubisz S., 2001: Gramatyka historyczna języka polskiego. Warszawa.

DudA B., LısczYK K., 2018: Narzędzia cyfrowe w polonistycznej dydaktyce akademickiej- zastosowania, możliwości, perspektywy. „Forum Lingwistyczne” nr 5, s. 143-154.

Eder M., Klapper M., Kotodziej D., 2015: Dawna polszczyzna i nowe technologie: testowanie metod przetwarzania języka naturalnego na materiale polskiego piśmiennictwa od średniowiecza po wiek XX. „Biuletyn Polskiego Towarzystwa Językoznawczego” nr 71, s. 189-202.

FAzlagić J., 2008: Charakterystyka pokolenia $Y$ [online: http://www.e-mentor.edu.pl/drukuj/artykul/ numer/25/id/549; data dostępu: 20.08.2019].

JADACKA H., 2005: Kultura języka polskiego. Fleksja, słowotwórstwo, składnia. Warszawa.

Klemensiewicz Z., 1952: Podstawowe wiadomości z gramatyki języka polskiego. Kraków.

Kopeска-PIECH K., 2011: Koncepcje konwergencji mediów. „Studia Medioznawcze” nr 3 (46), s. 11-25. 
KURек O., 2013: Wykładowca $w$ dobie aplikacji mobilnych i tabletów. W: Rozmus A., red.: Wykładowca doskonały. Podręcznik nauczyciela akademickiego. Warszawa, s. 241-251.

MAYER R., 2013: Uczenie się z wykorzystaniem technologii. W: Dumont H., Instance D., BeneviDES F., red.: Educational Research and Innowavation. The Nature of Learning: Using Research to Inspire Practise / Istota uczenia się. Wykorzystanie wyników badań w praktyce. Warszawa, S. 277-307.

MARKowski A., 2005: Kultura języka polskiego. Teoria. Zagadnienia leksykalne. Warszawa.

Morbitzer J., 2012: O istocie medialności młodego pokolenia. „Neodidagmata” 33/34, s. 131-153.

PAtKA P., KWAŚNICKA-JAnowicz A., 2017: Przewodnik po elektronicznych zasobach językowych dla polonistów (słowniki, kartoteki, korpusy, kompendia). Kraków [online: http://tmjp.pl/ima-ges/pdf/ przewodnik_po_elektronicznych_zasobach.pdf; data dostępu: 29.11.2017].

Prensky M., 2001a: Digital Natives, Digital Immigrants. Part 1. “On the Horizon” IX, no 5.

Prensky M., 2001b: Digital Natives, Digital Immigrants. Part 2: Do They Really "Think" Differently? "On the Horizon" IX, no 6.

Przepiórkowskı A., Buczyńskı A., Wilk J., 2011: Ściągawka do Narodowego Korpusu Języka Polskiego [online: http://nkjp.pl/poliqarp/help/plse1.html\#s2-10001; data dostępu: 31.07.2019].

Rospond S., 1971: Gramatyka historyczna języka polskiego. Warszawa.

SAjDuk B., 2014: Pokolenie Y a metody dydaktyki akademickiej. „Kultura i Polityka w Krakowie” nr 16 , s. $12-28$.

StIEBER Z., 1969: Zarys gramatyki porównawczej języków słowiańskich. Warszawa.

Spitzer M., 2007: Jak uczy się mózg. Warszawa.

Spitzer M., 2013: Cyfrowa demencja. W jaki sposób pozbawiamy rozumu siebie i swoje dzieci. Słupsk. SPITZER M., 2016: Cyberchoroby. Jak cyfrowe życie rujnuje nasze zdrowie. Słupsk.

Strauss W., Howe N., 1991: Generations: The History of America's Future, 1584 to 2069. New YorkLondon-Toronto-Sydney.

Strauss W., Howe N., 2000: Millennials Rising: The Nert Great Generation. New York.

SzEwKо W., 2012: Oto pokolenie Y [online: https://www.bankier.pl/wiadomosc/Oto-pokolenieY-2531947.html; data dostępu: 1.09.2014].

Woвalis M., 2017: W stronę cyfrowej dydaktyki akademickiej XXI wieku. Próba rozpoznania. „Scripta Neophilologica Posnaniensia" XVII, s. 435-454.

Wolińskı i in., 2018: Wolıńskı M., Kieraś W., Komosıńska D., Modrzejewski E.: Narzędzia przetwarzania tekstów historycznych [online: https://korba.edu.pl/static/documents/publikacje/2018_ uw_wolinski.pdf; data dostępu: 18.08.2019].

Woliński M., 2014: Morfeusz Reloaded. In: Calzolari N., Choukri K., Declerck T., Loftsson H., Maegaard B., Mariani J., Moreno A., Odijk J., Piperidis S., eds.: Proceedings of the Ninth International Conference on Language Resources and Evaluation. Reykjauík, s. 1106-1111. 